\title{
Evaluation of entomopathogenic fungi against the mealy bug on custard apple
}

\author{
S.S. DIXIT, G.B. KABRE* AND V.V. PATIL \\ Department of Agricultural Entomology, College of Agriculture, DHULE (M.S.) INDIA
}

\section{ARITCLE INFO}

Received : 30.06 .2016

Revised : 27.08 .2016

Accepted : 11.09 .2016

\section{KEY WORDS :}

Custard apple, Mealy bug, Entomopathogenic fungi

*Corresponding author: Email : kabregb@gmail.com

\begin{abstract}
Different entophathogenic fungi were evaluated in field trials at the instructional farm of Krishi Vigyan Kendra (KVK) Dhule provided by Department of Entomology, College of Agriculture, Dhule for the management of mealy bug on custard apple in Kharif season of 2014-15. All the treatments were observed to be effective in reducing mealy bug infestation on custard apple. Among the evaluated insecticide and biopesticides the treatment with Verticillium lecanii $7.5 \mathrm{~g} /$ lit. was recorded significantly lowest mealy bug population and was was at par with Verticillium lecanii $5 \mathrm{~g} / \mathrm{lit}$. (12.74). The next best treatments protection included Trizophos 40 EC $3 \mathrm{ml} / \mathrm{lit}$. (14.26) and it was at par with Verticillium lecanii $2.5 \mathrm{~g} / \mathrm{lit}$. (14.40). The next treatments in this respect were Metarhizium anisopliae $7.5 \mathrm{~g} / \mathrm{lit}$. (15.68), Metarhizium anisopliae $5 \mathrm{~g} / \mathrm{lit}$. (16.33), Beauveria bassiana $7.5 \mathrm{~g} / \mathrm{lit}$. (17.37), Metarhizium anisopliae $2.5 \mathrm{~g} / \mathrm{lit}$. (18.13), Beauveria bassiana $5 \mathrm{~g} / \mathrm{lit}$. (20.54) and Beauveria bassiana $2.5 \mathrm{~g} / \mathrm{lit}$. (22.25). There was an increase in mealy bug population in untreated check to the extent of 35.52 numbers of colonies as compared to treated plots.
\end{abstract}

How to view point the article : Dixit, S.S., Kabre, G.B. and Patil, V.V. (2016). Evaluation of entomopathogenic fungi against the mealy bug on custard apple. Internat. J. Plant Protec., 9(2) : 510-513, DOI : 10.15740/HAS/IJPP/9.2/510-513. 